\title{
Analysis on the Present Situation of Agricultural Catastrophe Risk Diversification in China
}

\author{
Guoqu Deng, Shujuan Kang, Kai Guo
}

College of Management, Henan University of Science and Technology, Luoyang 471023, China

\section{我国农业巨灾风险分散现状分析}

\author{
邓国取, 康淑娟, 郭 凯 \\ 河南科技大学管理学院, 洛阳 471023, 中国
}

\begin{abstract}
The Chinese government has been working to explore the spread of agricultural catastrophe risk management. The agricultural catastrophe risk diversification has experienced the financial leading mode and the financial support mode, at present has the transition to the multi-level risk dispersion model stage. Government has issued disaster prevention and mitigation laws and planning, agricultural insurance (reinsurance) policy and catastrophe reserve policy on agricultural catastrophe risk diversification for macro management. Government relief, social assistance and agricultural insurance are the main means to spread the risk of agricultural catastrophe in China, but there are the main problems of agricultural catastrophe risk diversification, the overall level of agricultural catastrophe loss compensation is very low and agricultural catastrophe risk dispersion ratio is not reasonable and so on. Agricultural catastrophe risk diversification is an important part of China's agricultural catastrophe risk diversification management, but the deep level of substantive international cooperation remains to be explored.
\end{abstract}

Keywords: Agricultural catastrophe, Dispersion model, Decentralized policies, Dispersion means

\section{摘要}

我国政府一直在致力于探索农业巨灾风险分 散管理。农业巨灾风险分散经历了财政主导模 式和财政支持模式, 目前已经过渡到多层次风 险分散模式阶段。先后出台了防灾减灾法律和 规划、农业保险 (再保险) 政策和巨灾准备金 政策等对农业巨灾风险分散进行宏观管理。政 府救灾、社会救助和农业保险是我国农业巨灾 风险分散的主要手段, 但存在着农业巨灾风险 分散的主体不足、农业巨灾损失补偿总体水平 很低和农业巨灾风险分散主体分散比例不尽 合理等问题。农业巨灾风险分散国际合作是我 国农业巨灾风险分散管理的重要内容, 但深层 次的实质性国际合作还有待我们去探索。

关键字: 农业巨灾; 分散模式; 分散政策; 分 散手段

我国农业巨灾发生的频率比较高, 每年造 成了巨大的财产损失和人员伤亡 ${ }^{[1]}$ ，另一方面， 我国一直在致力于探索农业巨灾风险分散管 理, 逐渐形成了中国特色的农业巨灾风险分散 模式, 出台了相关的政策和法规等宏观管理措 施, 不断完善农业巨灾风险分散路径, 初步开 展了农业巨灾风险分散国际合作, 但不可否认 的是, 目前我国农业巨灾风险分散在存在许多 问题。

\section{1. 积极探索农业巨灾风险分散模式 \\ 农业巨灾风险分散模式是指风险主体为} 了达到分散风险的目的, 为实现其所确定的价 
值定位而采取的某一类方式方法的总称, 包括 确定风险主体地位, 实现分散风险而规定的业 务范围, 以及风险主体通过什么途径或方式来 分散风险。

据此, 农业巨灾风险分散模式指风险主体 对农业巨灾风险作出反应的一种在特定环境 下有效的范式。回顾和分析我国农业巨灾风险 分散管理实践的发展历程, 结合不同时期农业 巨灾风险分散的环境、手段和工具等特征, 我 国一直在致力于农业巨灾风险分散模式的探 索。

\section{1财政主导模式（1949-1981）}

20 世纪 50 年代我国开始农业保险, 此后, 因为 “文革” 等原因停办, 直到 1981 年我国 农业保险才得以恢复。在此期间, 我国农业巨 灾风险分散主要依靠国家财政救灾, 农业保险 和社会捐赠微不足道。这个时期, 国家财政主 导了农业巨灾风险分散, 政府财政救助几乎成 为唯一的农业巨灾风险分散工具。

1. 2财政支持模式（1982-2013）

1982 年我国开始恢复农业保险, 特别是从 2004 年以后, 我国对农业保险开始进行财政 补贴, 也制定了一系列农业保险的税收优惠政 策和措施, 使得农业保险得到了快速发展, 农 业保险成为农业巨灾风险分散的一个重要手 段和工具。

与此同时, 随着我国人民收入水平的增长, 公民的公益意识逐渐提高, 各类公益组织不断 发展壮大, 国家捐赠活动的日益活跃, 使得我 国社会捐赠规模大幅度增长, 这些途径有效地 分散了我国的农业巨灾风险。

此外, 政府通过各种政策积极引导, 使得 各地区的巨灾风险准备基金不断壮大, 为我国 农业巨灾风险分散增加了一个有效路径。

尽管这个时期我国农业巨灾风险分散主 要依靠财政救助, 但已经探索出一条在我国财 政和税收等政策手段的支持下, 形成了越来越 多的农业巨灾风险分散路径, 政府财政救助不 再是机会唯一的分散工具。

1.3 多层次风险分散模式（2014一今）

我国国务院总理李克强在 2014 年 7 月召 开的国务院常务会议上明确了保险行业的重 要性, 指出要加速该行业的发展, 将保险运用 到灾害防范, 将其纳入救助体系。其明确指出
要建立巨灾保险制度, 并要求这种保险制度必 须以有财政支持作为后盾，商业保险作为平台， 构造多层次的风险分担 ${ }^{[2]}$ 。

该模式的主要特点: 一是政府财政支持。 因为农业巨灾风险的特殊性, 任何国家农业巨 灾风险分散管理都离不开政府财政的支持; 二 是强调了商业保险未来的重要性。在农业巨灾 风险分散过程中将扮演的主导作用, 农业巨灾 保险和再保险是未来商业化运作的重点; 三是 多层次性。多层次性不仅仅强调政府、市场和 私人 (主要是互助保险) 等农业巨灾风险分散 主体的多元性, 也强调包括财政救助、社会捐 赠（含国际捐赠）、保险、再保险、巨灾基金 和巨灾证券化等农业巨灾风险分散路径的多 元化, 这是我国未来农业巨灾风险分散模式的 最重要特征。

\section{2. 不断完善农业巨灾风险分散宏观管理}

农业巨灾在每个国家都有其独特的特征, 正是基于这种特征, 在我国农业巨灾现实情况 的基础上, 党和政府历来高度重视农业巨灾风 险管理, 先后出台了包括防灾减灾法律和规划、 历年中央一号文件、国民经济和社会发展、保 险发展规划等在内的一系列政策和措施, 积极 探索农业巨灾风险分散宏观管理。

2.1 防灾减灾法律和规划

(1) 防灾减灾相关法律

我国政府历来重视防灾减灾相关法律和 法规的建设和完善工作，除了突发事件应对法 这一基本应急法外, 目前已经出台的有《中华 人民共和国防震减灾法》、《中华人民共和国防 洪法》、《中华人民共和国水土保持法》、《中华 人民共和国森林法》、《中华人民共和国气象 法》、《中华人民共和国防沙治沙法》、《中华人 民共和国草原法》, 除了上述法律之外, 还包 括《中华人民共和国消防法》、《中华人民共和 国突发事件应对法》和《道路交通安全法》、 《地质灾害防治条例》等防灾减灾法律法规 ${ }^{[3]}$ 。 我国也制定了一些行政法规来约束某些 不法行为, 例如《草原防火条例》、《破坏性地 震应急条例》、《蓄滞洪区运用补偿暂行办法》、 《防汗条例》、《森林防火条例》等, 共计 30 余部。同时, 针对保险和救助等阶段也完善了 专门的规定, 已出台的有《自然灾害救助条例》、 


\section{Risk Analysis and Crisis Response in Big Data Era (RAC-16)}

《灾害事故医疗救援管理办法》、《救灾捐赠管 理暂行办法》等 ${ }^{[3]}$ 。

(2) 防灾减灾规划

在专项规划方面, 我国也颁布实施了一些 法律，如《中华人民共和国减灾规划》、《国家 综合减灾十一五规划》、《国家综合防灾减灾十 二五规划》、《加强国家和社区的抗灾能力: 2005-2015 年兵库行动纲领》和《亚洲减少 灾害风险北京行动计划》等，这些专项法规的 颁布使我国建立起了一套较为完善的减灾救 灾工作机制, 主要内容为由政府统一领导, 属 地管理为主, 各部门分工负责, 灾害分等级管 理 ${ }^{[3]}$ 。

1997 年国务院出台了《中华人民共和国减 灾规划》(1998-2010 年)，明确了: “减灾意 识需要进一步培养, 不仅仅是一部分公民减灾 意识的培养, 更主要的要增强全民意识的培养, 这不仅仅体现在生产中, 也要求公民在生活中 时时考虑减灾, 这就要求公民不断的开发新的 减灾手段, 运用多种减灾措施, 全面开展减灾 建设, 只有这样, 才能充分发挥各种减灾措施 的整体的效能，才能将减灾工作进一步的推 进。”同时，该法律也将减灾工作的主要任务 进行了重申: “要求减灾工程建设和非工程建 设同时加速发展, 保障运行机制的完善, 达到 减灾工作水平全面提高、减灾事业全面发展的 目的, 但是所有的这一切必须要求减灾工作与 国民经济发展的任务、目标以及国民经济和社 会发展的总体规划相一致。提出了农业和农村 减灾、工业和城市减灾、区域减灾、社会减灾 和减灾国际合作等工作的重要行动 ${ }^{[5]}$ 。

2007 年 8 月我国出台的《国家综合减灾十 一五规划》中明确指出 “要学会综合运用各方 面手段，包括法律、行政、市场、科技等，努 力建立起减灾管理体制与运行机制, 并不断对 其进行完善，对灾前预警、监测、防备、灾后 救助、应急处理以及重建能力进行加强, 使工 作重心从减轻灾害的损失程度到灾害风险预 警的转变, 全面综合提升灾害风险管理水平和 减灾能力, 使人们的人身财产安全得到切实的 保障，全面推进社会的可持续发展。”确定了 “以政府为主导、社会参与、分级管理; 区域 与部门共同协作、各负其责; 灾害风险的降低 和社会经济的可持续发展相互配合协调” 等
基本原则。“提升应对巨灾的综合能力。为了 达到此目标, 在研究巨灾时必须清晰地认识到 巨灾活动的规律、其发生的机理、还要了解其 与次生灾害的相互关系，从而达到对巨灾的全 面认知, 除了认知之外, 还应进行巨灾应急的 仿真实验和重大自然灾害变异模拟。完善应对 巨灾的机制体制，制定相应的政策措施，对巨 灾风险高发区域和重点城市群（比如 “长三 角”、“珠三角”、“环渤海” 等) 要加强巨 灾防范的演练, 以防巨灾来临之际手忙脚乱。 保险方面, 我们要积极探索出适合中国国情的 农业再保险体系, 推进农业保险试点, 争取找 到一个契合点, 使财政补助与政策性农业保险 相契合, 从而建立起完善的农业风险防范与救 助机制。在巨灾防御工作方面, 要加强合作, 建立亚洲区域巨灾中心, 努力探索出亚洲区域 在应对巨灾时应采取何种合作方式，降低巨灾 危害 ${ }^{[4]}$ 。

2011 年国务院出台了《国家综合防灾减灾 规划》(2011-2015 年), 该规划 “是贯彻落实 党中央、国务院关于加强防灾减灾工作决策部 署的重要举措, 该项规划不仅有力的推动了防 灾减灾事业的发展、构建了综合防灾体系，而 且在综合提高防灾减灾能力方面效果明显, 在 一定程度上对人民的生命财产安全和社会全 面协调的发展起到了积极的促进作用, 意义重 大”。提出了十项主要任务, 分别是, 加强自 然灾害监测预警能力、信息管理与服务能力、 风险管理能力工程防御能力、区域和城乡基层 防灾减灾能力、应急处置与恢复重建能力、科 技支撑能力、社会动员能力、人才和专业队伍、 文化建设等能力的建设，同时提出了国家救灾 物资储备工程、防灾减灾宣传教育、国家综合 减灾与风险管理信息化建设工程、环境减灾卫 星星座建设工程、国家重特大自然灾害防范仿 真系统建设工程、科普工程、全国自然灾害综 合风险调查工程、国家自然灾害应急救助指挥 系统建设工程、实施综合减灾示范社区和避难 场所建设工程等八项重大项目, 明确了完善工 作机制、建立健全法律法规和预案体系、加大 资金投入力度、广泛开展国家合作与交流、做 好规划实施与评估等五项保障措施 ${ }^{[3]}$ 。 2.2 农业保险、再保险管理

农业保险从 1982 年开始就恢复了, 之后 
Risk Analysis and Crisis Response in Big Data Era (RAC-16)

农业保险发展的非常健康, 尤其是 2004 年保 险试点工作展开之后, 发展极为迅猛, 保险区 域逐渐扩大, 保险品种迅速增加, 保费收入大 幅度提高, 保险密度和保险深度得到很大的提
升, 2013 年, 农业保险费同比增长 $27.4 \%$, 达 到了 306.6 亿元，承保农作物的面积相比于主 要农作物播种面积达到了 $42 \%$, 超过 10 亿亩, 为农业巨灾风险分散奠定了良好的基础 ${ }^{[6]}$ 。

表 1 我国保险费补贴的农业保险标的一览表

\begin{tabular}{|c|c|}
\hline 保费补贴来源 & 保费补贴标的 \\
\hline 中央财政补贴保费的种植业保险种类 & $\begin{array}{l}\text { 水稻、棉花、玉米、甘蔗、甜菜、油菜、小麦、青 } \\
\text { 稞 (青)、大豆、花生、土豆 (陇) 、橡胶树 (琼)、 } \\
\text { 森林 }\end{array}$ \\
\hline 地方财政补贴保费的种植业保险种类 & $\begin{array}{l}\text { 大棚蔬菜及大棚水果，如柑橘、香蕉、梨、西瓜、 } \\
\text { 苹果、葡萄 }\end{array}$ \\
\hline 中央财政补贴保费的养殖业保险种类 & $\begin{array}{l}\text { 能繁母猪、牦牛 (青、藏)、育肥猪、奶牛、藏系 } \\
\text { 羊 (青) }\end{array}$ \\
\hline 地方财政补贴保费的养殖业保险种类 & $\begin{array}{l}\text { 鸡、鸭、海参、鹅、虾、淡水鱼、蟹、海水 (网箱) } \\
\text { 养鱼 }\end{array}$ \\
\hline 地方财政补贴保费的涉农保险种类 & 农业机械、农房、渔船、渔民（人身意外伤害） \\
\hline
\end{tabular}

第八届全国人民代表大会常委会第十四 次会议上（1995 年 6 月 30 日）, 通过了《中 华人民共和国保险法》, 经过了近 15 年的发展 探索, 在第十一届全国人民代表大会常务委员 会第七次会议上（2009年 2 月 28 日), 《中华 人民共和国保险法》被成功修改制定 ${ }^{[8]}$ 。2012 年 11 月 12 日《农业保险条例》颁布实施, 通 过行政法规的形式予以强制执行 ${ }^{[9]}$ 。以上法律 直接为我国农业巨灾保险提供了基本法律依 据。

全国政协委员戴凤举在 2004 年 3 月份举 办的“两会”上, 呼吁建立农业巨灾保险制度, 该委员认为只有建立了完善的农业巨灾保险 制度, 才能更好的、更加有效的应对巨灾风险。 保监会早在 11 年前, 即 2004 年就已经开始着 手研究地震保险制度、农业保险制度, 明确农 业巨灾保险是我国保险业工作的重点, 致力于 我国巨灾保险制度框架的建立, 努力达到保险 业务服务国民经济、社会稳定、改革开放的总 目标。从 2004 年到目前为止, 党中央国务院 对加强农业巨灾风险制度尤为重视, 这种制度 也多次被提出。中共十六届三中全会 (2003 年 10 月）上，明确指出要对政策性农业保险 制度进行探索并建立, 农业保险在 2006 年被
作为支农方式的创新, 纳入农业保护体系 ${ }^{[10]}$ 。

国务院总理李克强主持召开国务院常务 会议 (2014 年 7 月), 主要针对现代保险服务 业加快发展的问题, 并指出纳入灾害事故防范 救助体系要不断纳入保险, 只有这样, 才能使 巨灾保险制度逐步得以建立，而且这种保险制 度也具有一定的特点, 它必须以有财政支持作 为后盾, 商业保险作为平台, 构造多层次的风 险分担 ${ }^{[11]}$ 。

国务院于 2014 年 8 月 12 日印发《关于加 快发展现代保险服务业的若干意见》(以下简 称《意见》), 该意见对现代保险业务的发展进 行了明确要求, 不仅提出了总体的要求, 明确 了重点的任务, 以及应采取怎样的应对措施, 同时对保险服务业的发展目标进行了规划, 该 目标要求到 2020 年, 我国要努力实现从保险 大国到保险强国的蜕变, 这一蜕变的前提是必 须大力发展与我国经济发展相适应的现代保 险服务业, 并且这种保险服务业要功能完善, 更加安全、诚实、信用、稳健、规范, 较强的 创新能力、服务能力、国际竞争力也是必不可 少的条件之一。该《意见》分别从 9 个方面提 出了 29 条政策性的措施, 相对较为全面, 提 出要 “将保险经济补偿机制进行进一步的完善, 


\section{Risk Analysis and Crisis Response in Big Data Era (RAC-16)}

灾害救助的参与度也要进一步的进行加强, 此 外, 灾害事故防范救助体系中应该将保险纳入, 建立巨灾保险制度”; 该《意见》同时强调 “将 支农惠农的方式进行不断的创新, 发展 “三农 保险”、扩宽其深度以及广度, 同时大力发展 农业保险” [10]

\section{3巨灾准备金管理}

2007 年，中央首次对江苏、吉林、湖南、 四川、新疆和内蒙古六个省区进行了政策性农 业保险的新试点, 对这六个省份提供了农业保 险补贴。其中, 四川和内蒙古两个省份将农业 保险经营的结余转为巨灾准备金, 江苏则是由 财政按照当年农业保险保费的一定比例拨付 专门的巨灾风险基金。

2008 年中央扩大了财政保费补贴的试点 区域, 新增了辽宁、河北、河南、山东、湖北、 江西、安徽、陕西、浙江、广东海南等 12 个 省区。这些省份都对农业巨灾风险分散进行了 一定程度上的探索, 大多数的省份已经对农业 巨灾准备金进行了提取, 其中, 河南、安徽等 省按照保费收入的一定比例提取巨灾风险准 备金, 江西按照农业保险独立核算账户会计年 度经营盈余的 50\%提取巨灾风险准备金, 江苏 出台了《江苏省农业保险试点政府巨灾风险准 备金管理办法 (试行)》, 建立了省市县三级巨 灾风险准备金。

国务院在 2012 年出台了关于转发《财政 部、国家税务总局关于保险公司农业巨灾风险 准备金企业所得税税前扣除政策的通知》的通 知, 该通知主要针对保险公司计提农业巨灾风 险准备金时，企业所得税税前的扣除问题。该 通知表明:

补贴险种在进行农业巨灾风险准备金计 提时, 不得高于补贴险种当年保费收入的 $25 \%$, 允许这些费用在企业所得税前扣除。公式如下: 本年度扣除的巨灾风险准备金 $=$ 本年度保费 收入 $\times 25 \%$ 一上年度已在税前扣除的巨灾风险 准备金结存余额。如果通过该公式计算后, 我 们发现数值为负, 应该增加应纳税所得额; 补 贴险种我们在此也给出了相应的定义: 确定的 依据主要是来源于财政部关于种植业保险保 费补贴管理的相关规定, 并且要求各级财政部 门的补贴的比例之和不得低于保费的 $60 \%$; 保 险公司应该时时严格要求自己, 坚持专款、专
项、专用的原则, 只有这样, 才能使巨灾风险 准备金管理与使用制度更加规范和完善。并且 企业在向主管税务机关报送时, 必须准备好相 关材料, 材料包括所得税纳税申报表与巨灾风 险准备金提取与使用的相关说明的报表。

2013 年财政部印发了《农业保险大灾风险 准备金管理办法》 (以下简称 “管理办法” ) 的通知 ${ }^{[10]}$, 该通知的目的非常明确, 农业保险 大灾风险分散机制的建立和完善不是一气呵 成的, 因此如何完善农业保险大灾风险分散机 制、如何规范提取农业保险大灾风险准备金显 得尤为重要, 只有这样, 才能使农业保险健康 持续的发展。“管理办法” 明确了大灾准备金 管理应该遵循独立运作、因地制宜、分级管理、 统筹使用等原则, 详细规定了大灾准备金的计 提办法, 对大灾准备金的使用和管理进行了明 确规定。

2014 年 5 月,上海市政府办公厅关于转发 市农委等四部门制订的《上海市农业保险大灾 （巨灾）风险分散机制暂行办法》的通知 ${ }^{[11]}$, 明确表示为了促进农业保险持续健康发展, 要 对本市政策性农业保险制度进行进一步完善, 农业保险大灾风险分散机制要进一步完善, 并 且这种保险要建立在财政支持的基础上, 尽可 能的多层次的进行分散。农业大灾风险主要是 指遭受特大暴雨、台风、病虫害 (疫病) 等人 为因素以外的不可抗拒灾害, 并且在某一公历 年度政策性农业保险业务赔付率超过 90\%的 灾害称为大灾风险; 农业巨灾风险主要是指在 某一公历年度政策性农业保险业务赔付率超 过 150\%。大灾准备金必须设立专户进行管理, 独立核算, 并且是准年滚存。大灾准备金的提 取是按照一定的比例从农业保险保费收入和 超额承保利润中计提。而对于那些在某一公历 年度政策性保险业务赔付率低于 $90 \%$ 的, 《办 法》中规定, 农业保险机构要全部承担这些费 用。赔付率在 90\%-150\%之间的, 农业保险公 司处于分散风险的目的, 需要进行再保险。赔 付率大于 $150 \%$ 的, 损失由农业保险大灾（巨 灾) 风险准备金和农业保险机构使用对应区间 的再保险赔款摊回部分。如果损失仍没有得到 弥补, 市、县财政需要对差额部分采用 “一事 一议” 的方式进行解决。对于赔付率在 $90 \%$ $150 \%$ 的政策性农业保险, 农业保险机构再保 
Risk Analysis and Crisis Response in Big Data Era (RAC-16)

险的购买需要市级财政部门根据情况给予适 当的保费补贴。但是这种补贴是有一定的标准 的，即为上年度农业保险机构购买相关再保险 保费支出的 $60 \%$, 但是最高限额只能是 800 万 元, 即不能超过 800 万的上限, 由市农委将再 保险保费补贴安排列入部门预算。

\section{3. 逐渐拓展农业巨灾风险分散路径}

农业巨灾风险分散主体是指承担农业巨 灾损失的公民或法人组织。从历史上看, 早期 我国政府财力是否有限, 农业巨灾风险几乎全 部由受灾农户自己承担。随着我国政府救灾资 金投入的不断增加, 政府救灾成为农业巨灾风 险分散的主导, 这个时期, 农业巨灾风险的分 散主要以国家财政为依托。但到了 20 世纪 80 年代以后, 农业保险成为农业巨灾风险分散的 一个重要手段和工具, 同时, 随着社会捐赠活 动的日益活跃, 社会捐赠逐渐成为农业巨灾风 险分散的有效路径, 各地区的巨灾风险准备基 金不断壮大, 为我国农业巨灾风险分散增加了 一个有效路径。进入本世纪, 以财政支持作为 后盾, 商业保险作为平台, 构造多层次的风险 分担为保障的巨灾保险制度正在被不断地探 索, 期待更加迅速地实现农业巨灾风险分散路 径的多元化。

目前我国农业巨灾主要通过受灾农户、各 级政府、农业巨灾保险企业(含再保险企业)、 社会救助组织等主体进行风险分散。不论是从 农业巨灾损失补偿总体水平, 还是从农业巨灾 风险分散的主体承担比例来看, 都存在一定的 问题（表2）。

3. 1 农业巨灾损失补偿总体水平很低

从农业巨灾损失分散比例历史发展情况 来看, 总体呈现上升态势 (图 2), 特别 2007 年以来, 我国农业巨灾风险分散比例大幅度提 高, 其中, 2009 年的农业巨灾损失补偿比例 达到 $30.78 \%$, 为历史最高, 尽管如此, 农业 巨灾损失补偿总体水平还是很低。根据测算, 1982 到 2012 年期间, 我国农业巨灾风险直接 经济损失总量为 68890.9 亿元, 但总的农业巨 灾风险分散额度为 7923.065 亿元, 分散比例 为 $11.5 \%$, 农户承担农业巨灾损失的比例高达 $88.5 \%$ 。

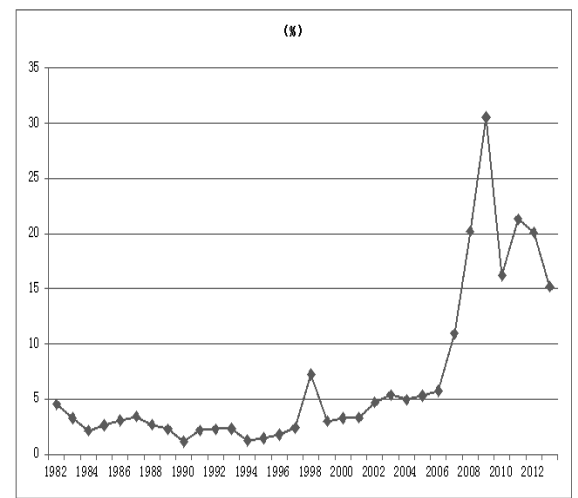

图 2 1982-2013 我国农业巨灾风险分散比例图

3. 2 农业巨灾风险分散主体分散比例不尽合理

目前我国农业巨灾风险分散的主体有受 灾农户、政府、社会救助组织、农业保险公司 等。受灾农户是我国农业巨灾风险分散的最大 主体，承担了农业巨灾风险损失的绝大部分， 其次是社会救助已经超过政府救灾, 成为我国 农业巨灾风险分散的重要路径, 尽管各级政府 部门和农业保险承担的比例不断增加, 但总体 比例还是不高（图3), 我国农业巨灾基金和福 利彩票 (从2011年开始) 也开始承担了部分农 业巨灾损失, 但目前比例非常低。这种受灾农 户承担绝大部分巨灾损失的现实使农户因灾 返贫的现象比较突出, 正所谓“十年致富奔小 康, 一场灾害全泡汤”, 同时, 政府和保险公 司压力巨大, 甚至不堪重负。

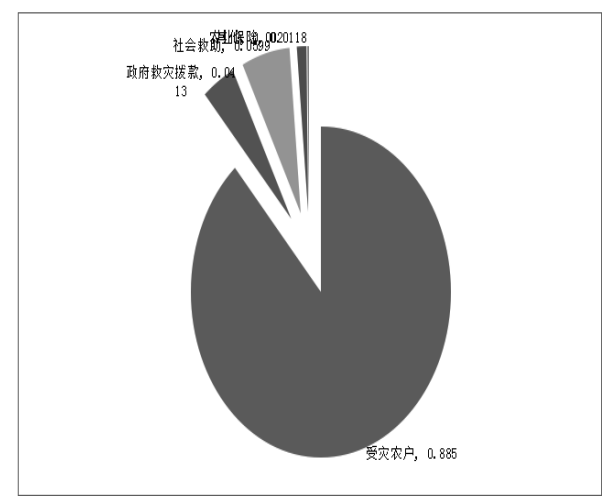

图 3 1982-2013 我国农业巨灾风险分散主体 累计分散比例图 
Risk Analysis and Crisis Response in Big Data Era (RAC-16)

表2 我国农业巨灾损失分散现状（单位: 亿元）

\begin{tabular}{|c|c|c|c|c|c|}
\hline 年份 & 农业巨灾损失 & 政府救灾 & 社会救助 & 农业保险 & 其他 \\
\hline 1982 & 169.5 & 7.64 & - & 0.0022 & - \\
\hline 1983 & 260.9 & 8.45 & - & 0.0233 & - \\
\hline 1984 & 361.4 & 7.4 & - & 0.0725 & - \\
\hline 1985 & 410.4 & 10.25 & - & 0.5266 & - \\
\hline 1986 & 384.2 & 10.64 & - & 1.06 & - \\
\hline 1987 & 326.3 & 9.91 & - & 1.26 & - \\
\hline 1988 & 438.6 & 10.64 & - & 0.95 & - \\
\hline 1989 & 525.0 & 10.90 & - & 1.07 & - \\
\hline 1990 & 616.0 & 5.20 & - & 1.67 & - \\
\hline 1991 & 1215.1 & 20.90 & - & 5.42 & - \\
\hline 1992 & 853.9 & 11.30 & - & 8.18 & - \\
\hline 1993 & 933.2 & 14.90 & - & 6.47 & - \\
\hline 1994 & 1876.0 & 18.00 & - & 5.38 & - \\
\hline 1995 & 1863.0 & 23.5 & - & 3.55 & - \\
\hline 1996 & 2882.0 & 30.8 & 15.8 & 4.15 & 0.05 \\
\hline 1997 & 1975.0 & 28.7 & 14.02 & 4.29 & 0.05 \\
\hline 1998 & 3007.4 & 83.3 & 113.21 & 5.63 & 15.13 \\
\hline 1999 & 1962.4 & 35.6 & 17.78 & 4.92 & - \\
\hline 2000 & 2045.3 & 47.5 & 16.3 & 3.21 & - \\
\hline 2001 & 1942.0 & 41.0 & 20.0 & 2.93 & - \\
\hline 2002 & 1717.4 & 55.5 & 20.8 & 2.91 & 1.35 \\
\hline 2003 & 1884.2 & 52.9 & 43.4 & 3.98 & 0.68 \\
\hline 2004 & 1602.3 & 40.0 & 35.1 & 3.52 & 0.45 \\
\hline 2005 & 2042.1 & 43.1 & 61.9 & 3.0 & 0.50 \\
\hline 2006 & 2528 & 49.4 & 89.5 & 6.0 & - \\
\hline 2007 & 2363 & 79.8 & 148.4 & 29.8 & - \\
\hline 2008 & 11752.4 & 1500 & 790.2 & 64.1 & 20.00 \\
\hline 2009 & 2523.7 & 174.5 & 507.2 & 95.2 & 44.52 \\
\hline 2010 & 5339.9 & 113.4 & 596.8 & 100.7 & 54.42 \\
\hline 2011 & 3096.4 & 86.4 & 490.1 & 81.8 & 0.80 \\
\hline 2012 & 4185.5 & 112.7 & 578.8 & 148.2 & 1.30 \\
\hline 2013 & 5808.4 & 102.7 & 566.4 & 208.6 & 2.60 \\
\hline 合 计 & 68890.9 & 2846.93 & 4125.71 & 808.5746 & 141.85 \\
\hline
\end{tabular}

3. 3农业巨灾风险分散主体风险分散方式增长 差异较大

政府救灾是我国传统的农业巨灾风险分 散方式, 尽管历年都在增长, 但增长的幅度并 不是很大。想比较而言, 社会救助发展迅猛, 已经成为农业巨灾风险分散最大的主体。农业 保险也在快速发展, 特别是从2004年政府实施 农业保险补贴以来, 快速成长为重要的农业巨 灾风险分散主体。农业巨灾基金和福利彩票从 无到有, 正在为我国农业巨灾风险分散做出较 大的贡献（图4、图5、图6)。

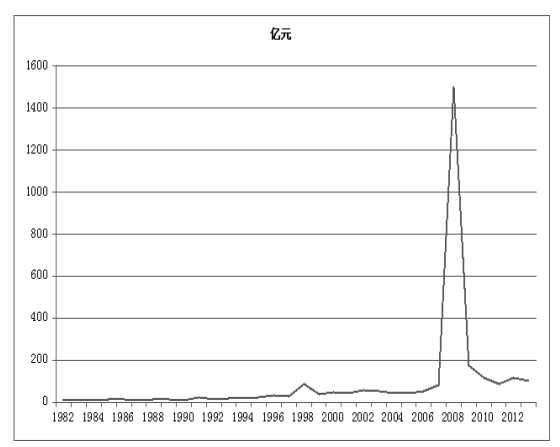

图 4 1982-2013 我国农业巨灾风险分散政府 救灾投入图 


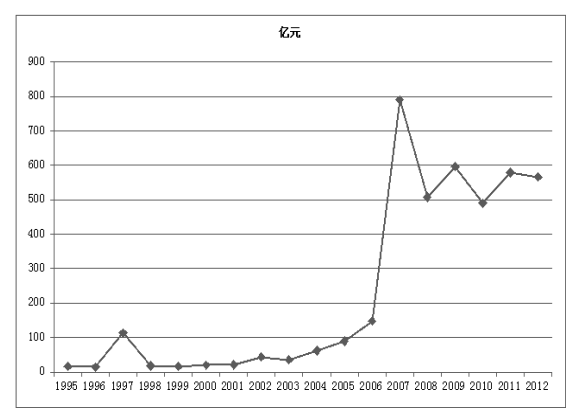

图 5 1995-2013 我国农业巨灾风险分散社会 救助投入图（单位: 亿元）

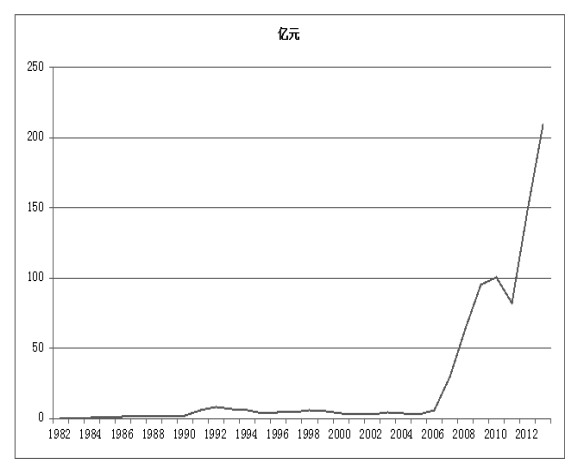

图 6 1982-2013 我国农业巨灾风险分散农业 保险投入图（单位: 亿元）

3.4 农业巨灾风险分散的主体不足

目前我国农业巨灾风险分散主体有受灾 农户、各级政府、农业巨灾保险企业（含再保 险企业)、农业巨灾基金、社会救助组织（包 括国内外各类社会救助组织) 和中介组织。与 国外的农业巨灾风险分散主体相比较, 缺乏金 融组织的参与，保险、证券、期货、银行等金 融组织已经成为国外农业巨灾风险分散的主 要力量, 银行提供紧急贷款、甚至无息贷款, 更多的是利用巨灾风险证券化分散农业巨灾 风险, 承担了 $50 \%$ 以上的农业巨灾风险损失。 因此, 积极培育和发展农业巨灾风险分散主体, 优化农业巨灾风险分散机制就具有非常重大 的理论和现实意义。

\section{4. 积极参与农业巨灾风险分散国际合作}

1989 年, 针对联合国提出的开展 “国际 减灾十年” 活动的倡议, 我国政府给予了积极
响应, 拉开了我国农业巨灾风险分散国际合作 的序幕。此后, 中国政府积极参与农业巨灾风 险分散国际合作, 实施区域协同农业巨灾风险 分散战略。

从 2005 年 9 月起, 在中国等政府的倡导 下, 到 2014 年截止, 连续举办了六届亚洲部 长级减灾大会, 其中, 中国政府在北京主办了 第一届亚洲部长级减灾大会, 此后分别在印度 的新德里、马来西亚的吉隆坡、印度尼西亚的 日惹市、韩国仁川和泰国曼谷等地主办了 5 届 亚洲部长级减灾大会。这几届大会有许多意想 不到的收获, 一系列文件也一一被过, 包括《亚 洲减少灾害风险北京行动计划》、《2007 亚洲 减少灾害风险德里宣言》、《2008 亚洲减少灾 害风险吉隆坡宣言》、《亚太 2010 年减轻灾害 风险仁川宣言》、《适应气候变化减轻灾害风险 仁川区域路线图》、《仁川行动计划宣言》、《亚 太 2014 年减轻灾害风险曼谷宣言》等合作文 件。会议采用多样化的形式, 包括部长对话形 式、圆桌会议形式、技术会议形式、专题会议 形式、全体会议形式和边会形式, 进一步的分 析亚太地区风险形势, 对利益做关方、各国政 府减灾抗灾过程的经验和教训都进行了分享、 交流, 特别对制定 HFA2 的相关问题进行了深 入探讨和碰商。指出对利益做关方、各国政府 应采取如下措施来进行防灾减灾: 增加对基层 社区的投入, 提高基层社区的抗灾能力, 私营 企业机构也要积极加入进来, 加强合作, 发展 科技，同时资金使用的透明度问题也至关重要。 以人为本的发展模式仍然贯穿始终, 妇女儿童、 残疾人、青少年、媒体、私营机构、红十字会 等各个组织要充分发挥作用, 努力将防灾减灾 和气候变化与可持续发展的目标相结合。各国 政府要完善法律, 加强法律框架建设, 支持红 十字会, 不要忽视小型灾害。地区内 37 个国 家红十字会 (红新月会) 向大会承诺, 进一步 加强基层社区减灾能力, 加强投入, 加强与私 营机构在减灾方面的合作 ${ }^{[12]}$ 。

中国政府的的作用非常巨灾，推动了上海 合作组织成员国在救灾方面的共同协作，上海 合作组织成员国紧急救灾部门领导人的首次 会晤是 2002 年 4 月在俄罗斯圣彼得堡进行的, 第二年, 在北京, 上海合作组织针对《上海合 作组织成员国政府间救灾互助协定》问题, 专 
Risk Analysis and Crisis Response in Big Data Era (RAC-16)

门组织了专家级会议, 这次会议主要是对提出 的问题进行深入的、更加进一步的探讨和磋商， 2005 年 10 月, 一个历史性的时刻在莫斯科诞 生, 这就是《上海合作组织成员国政府间救灾 互助协定》正式签署的时刻。上海合作组织成 员国紧急救灾部门领导人的第二次会议于 2006 年 11 月在北京如期召开, 《上海合作组织 成员国 2007-2008 年救灾合作行动方案》被 创造性的通过, 构造了一个新的行动框架, 包 括边境区域救灾、信息交流、人员研究、救灾 联络、技术交流 ${ }^{[14]}$ 。

在 2005 年 1 月 $18-22$, 日本兵库县神户市 举行了世界会议, 主要针对的问题是减少灾害, 《2005-2015 年行动纲领: 加强国家和社区 的抗灾能力》(下称《兵库行动纲领》) 被通过。 会议明确了从战略系统的角度处理风险, 从而 减轻风险的危害。会议要求加强国家以及社区 抗灾能力, 认为这是必须要达到的目标, 并为 达到该项目标确定了各种途径。中国加入《兵 库行动纲领》是在 2005 年, 从实施到现在, 在结合中国国情进行实施的过程中, 我国在组 织体系完善、工作机制健全、工作措施不断强 化、综合减灾能力提升方面取得了巨大的成效 [15]。

总体看来, 我国现有巨灾风险分散国际合 作主要集中在国际救援、信息共享、技术合作 研发、人才培养、学术交流和灾后重建等方面, 笔者认为这些都是初步和浅层次的事务性国 际合作, 农业巨灾风险分散国际合作的核心是 通过利用国际资源, 运用传统和非传统的分散 工具, 实现农业巨灾风险跨国间分散的行为, 因此, 深层次的实质性国际合作还有待我们去 探索。

\section{参考文献:}

[1] Tim Wheeler, Joachim von Braun. Climate Change Impacts on Global Food Security. Journal of Risk Analysis and Crisis Response, 2013 (8) : 508-514.

[2]中华人民共和国国务院. 国家综合防灾减 灾规划（2011-2015 年） [EB/OL].

http://www. chinanews. com/gn/2011/12
$-08 / 3518900$. shtml

[3] 中华人民共和国国务院新闻办公室. 中国 的减灾行动 $[\mathrm{EB} / \mathrm{OL}]$. http://big5. gov. cn/gate/big5/www. gov. cn/zwgk/2009-0 5/11/content_1310227. htm

[4] 中华人民共和国国务院. 中华人民共和国 减灾规划（1998-2010 年） [EB/0L]. http://cfg. fabao. cn/falvfagui/bwgfx $w j / n 214165307 . s h t m 1$

[5]中华人民共和国国家民政部. 国家综合减 灾“十一五” 规划 $[\mathrm{EB} / \mathrm{OL}]$. http://www. mca. gov. cn/article/zwgk/jhgh/200801 /20080100009537. shtml

[6] 中国保险年鉴编委会. 2013 中国保险统计 年鉴 [M]. 北京: 中国统计出版社, 2013

[7]度国柱. 中国农业保险的政策及其调整刍 议. 保险职业学院学报, 2014, 28 (2) : :22-27

[8]中华人民共和国人民政府. 中华人民共和 国保险法 [EB/OL]. http://www. gov. cn/ flfg/2009-02/28/content_1246444. htm

[9]黄英君, 史智才. 农业巨灾风险管理的比较 制度分析:一个文献研究. 保险研究, 2011 (5): 117-127

[10] 中华人民共和国国务院. 关于加快发展现 代保险服务业的若干意见 [EB/OL]. http://news. xinhuanet.com/politics/ 2014-08/13/c_1112064087. htm

[11] 中华人民共和国财政部.农业保险大灾风 险准备金管理办法 $[\mathrm{EB} / \mathrm{OL}]$.

http://www. gov. cn/zwgk/2013-12/19/c ontent 2550904. htm

[12] 上海市政府办公厅. 上海市农业保险大灾 (巨灾) 风险分散机制暂行办法 $[\mathrm{EB} / \mathrm{OL}]$. http://www. shanghai. gov. cn/shanghai /node2314/node2319/node12344/u26ai3 9315. html

[13] 中华人民共和国民政部. 李立国部长赴泰 国参加第六届亚洲减灾部长级大会 [EB/OL]. http://www. mca. gov. cn/article/zwgk/ mzyw/201406/20140600659008. shtml

[14]史培军. 中国综合减灾 25 年: 回顾与展望. 中国减灾. 2014（5): 32-35

[15] 度国柱. 加大财税支持力度, 促进农业保 险健康发展 $[\mathrm{N}$. 中国城乡金融 报, 2013-12-11 